\title{
Vulnerability of dryland agricultural regimes to economic and climatic change
}

\author{
Patrick G. Lawrence $^{1}$, Bruce D. Maxwell ${ }^{1}$, Lisa J. Rew $^{1}$, Colter Ellis $^{2}{ }^{2}$ and Anton Bekkerman $^{3}$
}

\begin{abstract}
Large-scale agricultural systems are central to food production in North America, but their ubiquity could be threatened by vulnerability to economic and climatic stressors during the 21 st century. Prior research has focused on understanding the influence of climatic changes on physiological processes in these systems and has increasingly recognized that other factors such as social, economic, and ecological variation and the interaction among these factors may cause unexpected outcomes. We assess the vulnerability of large-scale agricultural systems to variation in multiple stressors and investigate alternative adaptation strategies under novel conditions. We examine dryland farms in Montana's northern Great Plains (NGP), which represent large-scale semiarid agricultural systems that are likely to be affected by climate change. Farmers in the NGP have experienced three distinct periods of economic- and drought-related stressors since the 1970 s, primarily driven by uncertainty in soil moisture, but at times amplified by uncertainty in nitrogen fertilizer and wheat prices. We seek to better understand how farmers evaluate and respond to these conditions. The results indicate that although farmers perceived few alternative agronomic options for adapting to drought, strategies for adapting to high input prices were more plentiful. Furthermore, we find that increasing the overall resilience of dryland agricultural systems to economic and climatic uncertainty requires intrinsic valuation of crop rotations and their field-specific response to inputs.
\end{abstract}

Key Words: adaptation; drought; dryland agriculture; economics; experimentation; resilience

\section{INTRODUCTION}

Crop production in North America is overwhelmingly represented by large-scale monoculture or biculture commodity farms. With increasing recognition of potential climate change impacts on agricultural production (e.g. Lobell et al. 2008), there is elevated concern over the vulnerability of existing commodity farming systems to changes in temperature and precipitation (Hatfield et al. 2011). Simultaneously, increased variability and uncertainty about commodity and input prices over the last decade (Whitlock et al. 2017) has made farm management decisions more challenging. Together, these stressors have the potential to threaten a large number of commodity-reliant farms. However, individual farm impacts are affected by the magnitude and variability of the stressors, the tools that farmers have to understand the resilience of their systems, and the ability of farmers to assimilate new practices that are better adapted to new climates (Berkes et al. 2007, Tarleton and Ramsey 2008).

Changing precipitation, temperature, and evapotranspiration are likely to have the largest impacts on crop production in locations that are already subject to heat and drought stresses (Delgado et al. 2011). Consequently, arid and semiarid dryland agroecosystems could represent early warning locations for observing the impacts of climate change on farm sustainability. Any impacts would be manifest in reduced harvests of spring and winter wheat (Triticum aestivum), two of the major dryland agroecosystems crops. Both are tolerant to low moisture levels but may not withstand further reductions. Obvious methods of improving water use efficiency for wheat are already in use; attaining greater efficiency would require improvements such as enhancing the incorporation of crop residues into soil, careful crop cultivar selection, flexible rotations, and improvements in the timing of cultural operations (Nielsen et al. 2005).
Given the importance of wheat in dryland agriculture, fluctuations in wheat market prices have a significant impact on farm revenues. Hedging strategies, such as establishing forward and futures contracts in advance of the harvest date, are effective measures for mitigating some price risks, but they require the capacity to store large quantities of grain for long periods of time, and are not used by a majority of farmers (Mishra and El-Osta 2002, Velandia et al. 2009). High levels of fertilizer use, which have become more commonplace in the USA since 1980, further expose farmers to global energy price uncertainties because fertilizer is the largest energetic input into the system (Piringer and Steinberg 2006). Together, farms' exposure to risks in the commodity markets and energy markets creates a financial vise that tightens and loosens in response to the volatility of global financial markets and is out of the control of the farm manager.

Farmers' ability to withstand the economic vise, while under pressure from climate change, depends on the available mitigation tools (Howden et al. 2007) and on the adaptability of farmers (individually and collectively) to novel conditions (Berkes et al. 2007). Historical events (McLeman et al. 2008), farmer perceptions of risk and uncertainty (Sunding and Zilberman 2000), and pathways of social agricultural learning (Roling and Jiggins 1998) all lend insight into the adaptation process. Furthermore, qualitative understanding of the relationship between information sharing, learning, adaptive capacity, and resilience can create a window into farmers' adaptability and how it may be enhanced to endure climate change and fluctuating prices (Tarnoczi 2011).

To explore the vulnerability of dryland agroecosystems, we chose to focus on a geographical region that is already strongly influenced by climate change and economic fluctuations. The northern Great Plains (NGP) of Montana (Fig. 1) is an

${ }^{1}$ Land Resources and Environmental Sciences Department, Montana State University, ${ }^{2}$ Department of Sociology and Anthropology, Montana State University, ${ }^{3}$ Department of Agricultural Economics and Economics, Montana State University 
agricultural region that primarily produces dryland wheat, has a semiarid climate ( $<400 \mathrm{~mm}$ per year), and is dominated by large farms, e.g., greater than 800 ha. Previous studies have examined the adaptation process in the Canadian prairies (Bradshaw et al. 2004, Tarnoczi 2011), the adoption of sustainable agricultural practices in Montana (Saltiel et al. 1994), and quantitative methods for explaining farm-scale vulnerability within the context of climate (Antle et al. 2004). Our research adopts a hybrid methodological approach that explores the link between the quantitative reality of economic and climatic stress (manifested as the risk of bankruptcy) and qualitative farmer perceptions of adaptability. Specifically, we sought to understand how historical and current uncertainty of these stressors influence farmer vulnerability and adaptability.

Fig. 1. The northern Great Plains ecoregion.

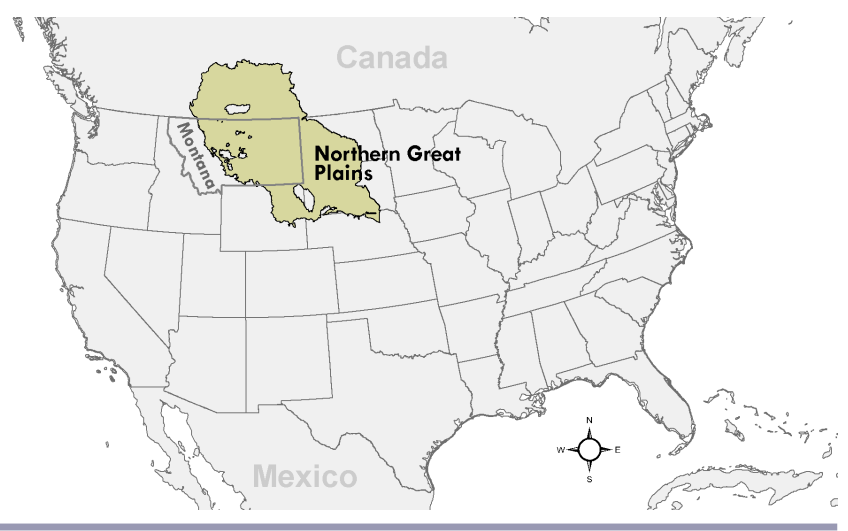

To study this question, we first reviewed the current economic vulnerability of Montana's NGP farmers within a historical context. It was expected that since the date when reliable farm census and survey data became available (1970), farmers have become more reliant on external inputs. Therefore, fluctuations in the price of inputs and the price of wheat could have significant impacts when unmatched by contemporaneous yield increases. Drought conditions could exacerbate these economic pressures by reducing yields and net returns. Next, the research explored the number and quality of options that farmers have to mitigate the impacts of these stressors. We sought to understand how the uncertainty and complex interactions of the stressors affect farmers' strategies for remaining economically solvent. Together, the physical reality and responses to uncertainty have important implications for the resilience of dryland agricultural systems.

\section{METHODS}

We use a mixed methods research approach that compares price and drought stress data with qualitative information about farmer perceptions to better understand the dynamics of physical stressors and how farmers manage for their uncertainty.

\section{Historical analysis: economic and drought variability}

To assess farmers' perception toward economic uncertainty, we focus on two factors that farmers believe to be the primary determinants (other than yield) of profitability: nitrogen cost and wheat prices. The Palmer Drought Z-index (PZI), averaged over the growing season months (April to August), was used as a quantitative indicator of moisture stress because it is the moisture index most highly correlated with yields in the NGP (Quiring and Papakryiakou 2003). To assess the uncertainty in these variables, the coefficient of variation $(\mathrm{CV})$ was calculated for each measure on a 5-yr rolling basis between 1965 and 2014. The CV is a unitless measure that allows variability of variables measured on different scales to be compared. High $\mathrm{CV}$ values indicate periods with elevated variability, suggesting higher uncertainty for farmers in the preceding 5-yr period. CV measures were determined separately for each stressor and were then additively combined into a measure of total variability.

Prices for nitrogen and wheat were obtained for 1960-2013 (USDA-NASS 2015a,b). A single aggregate wheat price was used for analysis; this was constructed by weighting the winter and spring wheat prices to reflect the annual proportion of winter wheat and spring wheat hectares planted in Montana (USDANASS Quickstats 2015). Montana was used as a representative subset of the NGP to facilitate social data collection and correspondence with census and survey data boundaries. Nitrogen fertilizer prices were weighted by the proportion of each fertilizer type used in each year (USDA-NASS MT 2011). Both fertilizer and wheat prices were converted to real prices using Consumer Price Index data (Bureau of Labor Statistics 2015) with 1980 as the baseline year. PZI data for climate district 3 in Montana were obtained from the National Climatic Data Center (2015).

\section{Farmer perceptions of uncertainty and adaptation}

We used a multistage inquiry procedure to understand the options available to Montana's NGP farmers and learn about their adaptations to uncertainty. Given the spatial heterogeneity of climate in Montana (despite regional similarities), the responses of farmers to drought were interpreted with the knowledge that each farmer may experience different conditions within the same growing season. Additionally, all of the farmers interviewed and surveyed all produced greater than $80 \%$ of their crops without irrigation, minimizing irrigation as a confounding factor.

First, we conducted in-depth semistructured interviews with three farmers to generate initial knowledge on adaptability and beliefs. A nonprobability sample of participants was intentionally selected based on expertise and experience making nutrient and crop rotation decisions in the NGP (Maxwell 2013). These interviews were conducted on-farm and lasted between two and three hours. Open-ended questions were asked about five potentially impactful forms of uncertainty: drought, weeds/pests, input prices, crop prices, and uncertainty in spatially varying crop responses and nutrient levels. As an example, each participant was asked, "How do you prepare for the growing season when the crop prices prior to planting are highly variable?" The respondents also discussed other relevant forms of uncertainty. Thus, while we adopted a "top-down" approach where the set of conditions potentially causing vulnerability were assumed (Cutter 1996), we also allowed for more flexible responses that did not fit with our preconceptions (Pittman 2011).

Interviews were digitally recorded, transcribed, and systematically coded (Miles and Huberman 1994). An initial codebook of emergent themes was based on the specific areas of inquiry but was expanded to incorporate emergent dimensions through an iterative coding process (Strauss and Corbin 1998, Lofland et al. 2006). Codes that appeared frequently across interviews included 
Fig. 2. Clockwise from upper left: kilograms of fertilizer used on a per-hectare basis in Montana, 1970-2012; trends in real (inflation-adjusted) nitrogen and wheat prices, 1970-2012; coefficients of variation for preceding 5yr periods, 1970-2012; area-weighted wheat productivity trends, 1970-2012.
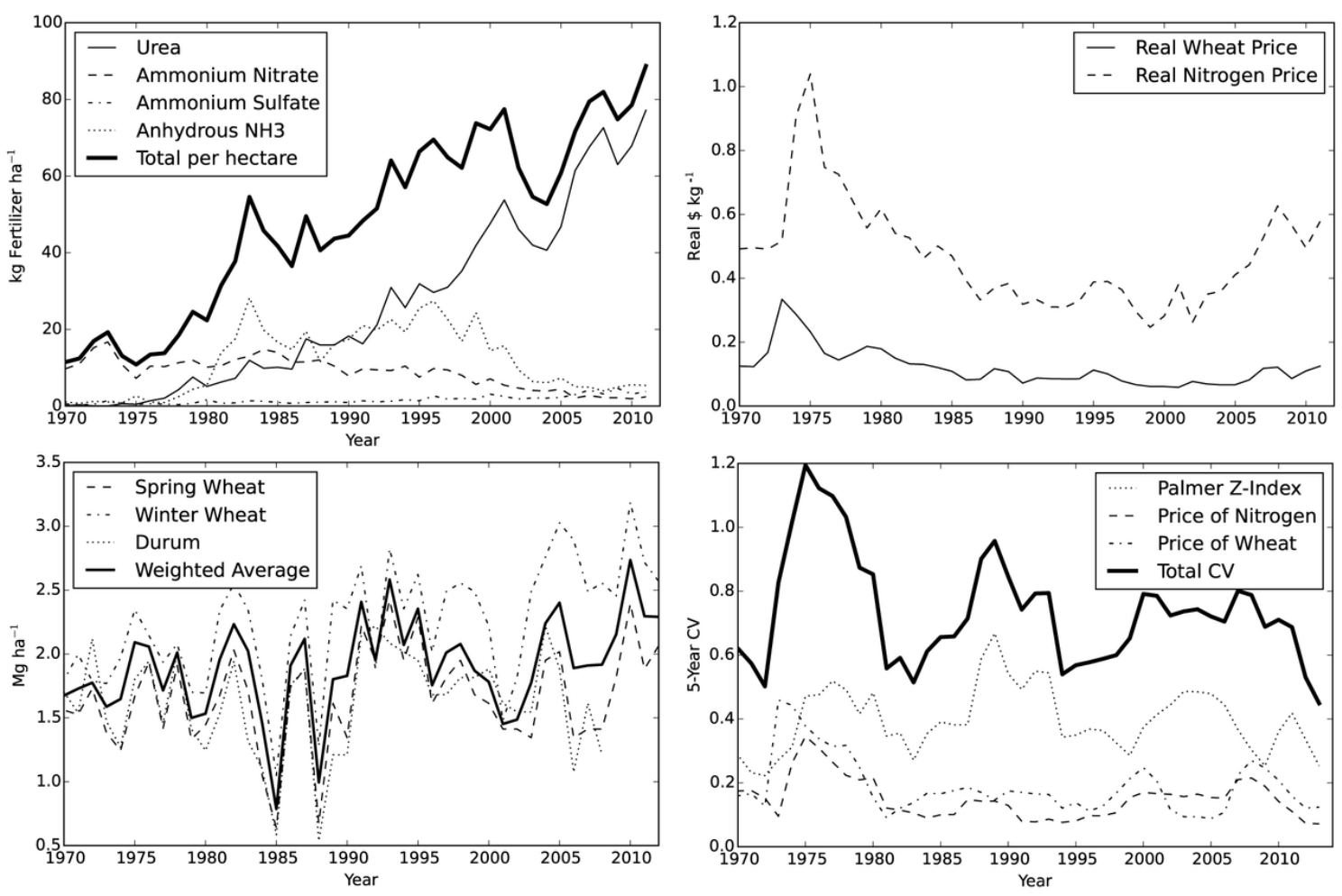

the dire and restrictive impacts of drought, the primary importance of prices, and the value of experimentation; these codes informed subsequent data-gathering steps.

Seventeen additional interviews were then conducted to further explore and focus the themes identified in the initial interviews and to provide detail to the impactful forms of uncertainty. These half-hour to hour-long interviews were conducted both by phone and in-person to capture a nuanced understanding of farmers' reaction to conditions observed throughout the growing season. These farmers were selected using a convenience sample of producers attending Montana Grain Growers Association (MGGA) conferences. The interviews were transcribed, coded, and used to refine and validate findings from the previous interviews. Quotes included in the results section are illustrative of general themes that emerged across multiple participants. Findings were then used to inform the next stage of inquiry.

These qualitative interviews were used to develop a survey instrument (Dillman 2000) aimed at clarifying the themes relating to perceptions of stressors and adaptations. Using in-person and web-based surveys, drought and extreme event scenarios were designed and respondents were then asked to describe their agronomic responses to the scenarios and where they would seek additional information needed for adaptation. Questions covering the same subject matter were posed with several alternative wordings (open-ended and multiple-choice) to validate responses. We also collected information about age, length of farming experience, irrigation status (irrigated or dryland), and operation size; the primary stressors outlined in the case study interviews were also validated. Data were used for respondents who matched the following criteria: farming was the primary occupation, wheat or other small grains were primary crops, and the farm was larger than 500 acres. The surveys were administered to farmers associated with the (MGGA) and farmers attending workshops on herbicides and precision agriculture facilitated by Montana State University Extension Specialists. Fifty-four of 718 surveys were returned. Given the retrospective nature of the survey and interview data, links between the quantitative and qualitative farmer responses were explored, but definitive cause-effect relationships were not established.

\section{RESULTS}

Historical patterns of economic and climatic vulnerability

Unstable input and market prices and uncertain moisture availability can negatively impact farms by inhibiting long-term operational and agronomic planning; each can affect a farm individually or through additive or multiplicative effects. Figure 2 provides a historical perspective of the variability in these three stressors. From 1970, overall per hectare fertilizer use consistently increased (Fig. 2), but prices during this period varied significantly. Nitrogen fertilizer and wheat prices declined from a maximum in 1972-1975 to a minimum in 1998, then peaked again in 2008 (Fig. 2). In all cases, input price spikes were caused by 
external events, related to oil and geopolitical crises in the $1970 \mathrm{~s}$ and farm policy in the 2000s, rather than farmers' behaviors.

Additionally, the spread between the nitrogen and wheat prices fluctuated substantially, likely impacting farmers' net returns. Notably, the spread has widened since 2002, with increases in nitrogen prices outpacing the associated increases in wheat prices. Although the productivity per unit area also increased since 1970 and there were changes to the variable and fixed farming costs (making identification of the net impact on returns difficult), nitrogen and wheat prices are the major determinants of net revenue and their widening spread is suggestive of increased economic stress. The PZI was more variable than prices, with elevated periods of moisture stress during the early and late 1980s and during the early-mid 2000s.

Changes in price and moisture levels certainly affect farmers' net returns, but variability in these factors may also have a significant impact by creating uncertainty. Three notable peaks were observed in the 5-yr CV indicator of total variability: in the midlate 1970s, in the late 1980s, and throughout the 2000s (Fig. 2, lower right panel). The first peak was the only period of uncertainty driven by all three input factors (nitrogen price, wheat price, and PZI), whereas the second was driven by the PZI alone, and the third by prices and the PZI during alternate time periods. The peak in the late 1980s corresponded with the previous five years of serious drought, which was associated with many farm exits (USDA ERS 2002).

Depending on the age and experience of individual farmers, the high levels of variability in the late 1980s and the 2000s are likely to be remembered by farmers and reflected in their past and current strategies of stress adaptation. In general, increased stress and variability creates a more difficult situation for agricultural management and increases vulnerability. However, the reactions of farmers strongly influence the impacts of the stressors and their longer term consequences.

\section{Number and quality of options for mitigating stressors}

Farmers experienced several distinct periods of acute stress in the last 45 years from drought, prices, or both. The reactions of farmers to the stressors and their relative desire to minimize the associated risks have the potential to structure their agronomic decisions and future vulnerability.

\section{Drought}

All farmers perceived drought as a major limitation to making agronomic changes. The interviewees' most common analogy was having their "hands tied." One farmer explained, "You just tighten the belt, you don't buy new stuff, ... you just get by. I'd say more just cut back the costs, try to be conservative." The specter of drought was frustrating for many largely because it removed their perceptions of control over their own farming systems:

Well, the biggest change I've had to, and still am responding to, is drought! You know, nothing works anymore because we don't get any rain... [It's] pretty much out of our hands as to what we can do.

The farmers also expressed that the only available option was to revert to agricultural practices (primarily wheat-fallow rotations and reduced crop diversity) that they had been using for generations. These practices were not necessarily viewed as ideal, but were perceived as the only available fallback. One farmer noted the following:

... in Montana, we are always just a week away from a
drought. ... I think we're doing about as good a job as we
can with managing the moisture that we get ... There's
room to allow for less moisture by changing our rotation
some. But winter wheat is probably the most efficient
water user that we have ... So we'd probably peel back to
fewer spring wheat acres, fewer pea acres, which is painful
to say. Or maybe we'd just quit recropping. We'd go from
two-thirds cropped every year to 50-50 or maybe even
less... But summer fallow is not very efficient.

Thus the semiarid nature of the NGP along with its climatic heterogeneity appeared to shape farmers' perceptions that their only available option was a rotation of winter wheat-fallow. Leguminous rotations were perceived to have benefits with respect to pest management and nitrogen fixation, but farmers still placed higher value on the perceived superior water-use efficiency of winter wheat. In drought years, their instincts favored the conservative crop rotation, while recognizing that short-term survival was being prioritized over long-term agronomic and environmental sustainability.

Drought was perceived to occur frequently, yet the timing of moisture availability on inter- and intra-annual time scales was still regarded as unpredictable, preventing farmers from planning for years when water was more plentiful. This unpredictability made it difficult to plant crops perceived to have longer term benefits (such as legumes) when it was uncertain whether the moisture would be available to realize those benefits. However, even with the prospect of short-term consequences, there were several outlying farmers who tried to make long-term plans for drought, a perspective more common among organic farmers (Tarnoczi 2011). One farmer described his cropping strategy:

... a long-term crop management system, so that what
you do builds your soil so that you can withstand
drought... on our farm, we fairly consistently raise spring
wheat, winter wheat, durum, peas, lentils, and either
canola, soybeans, ... So we're pretty diversified. Our soil
organic matter is increasing... each $1 \%$ stores another
inch of water. In a drought situation that one inch is the
difference between failure and just average.

This view was expressed by a minority $(11 \%)$ of interviewed farmers; with the arrival of a new period of drought, especially if accompanied by economic distress, the majority of NGP farms would likely revert to wheat-fallow. The survey data were consistent with this finding, albeit with a substantial level of variability. When asked about their short-term response to drought, a majority of farmers indicated that they would only sow one alternative crop ( $31 \%$ ), and fewer farmers responded that they would sow two $(28 \%)$, three $(11 \%)$, four $(6 \%)$, and six $(1$ respondent) alternative crops. The specific crops mentioned were highly variable, with the largest numbers of farmers suggesting wheat, which is already the dominant crop, or that they were unsure or needed more information.

Farmers' drought management practices (excluding planting alternative crops) were also very limited, with many of the practices, such as no-till, already being used. Other responses 
reflected this lack of options (Table 1), and included reducing continuous cropping $(8.7 \%)$, lowering yield goals to reduce fertilizer use $(10.9 \%)$, seeding at earlier dates $(6.5 \%)$, and fallowing $(8.7 \%)$.

Table 1. Summary of the management practices farmers reported they would use in response to extended drought (multiple options permitted).

\begin{tabular}{lc}
\hline \hline Management Practice & Respondents $(\mathrm{n}=46)$ \\
\hline lower yield goals/fertilization rate & $10.9 \%$ \\
less continuous cropping/recropping & $8.7 \%$ \\
fallowing & $8.7 \%$ \\
no-till & $8.7 \%$ \\
change seeding dates & $6.5 \%$ \\
stripper header & $6.5 \%$ \\
reduce costs & $4.3 \%$ \\
cover crops & $4.3 \%$ \\
water efficient crops & $4.3 \%$ \\
not sure/no change & $15.2 \%$ \\
\hline
\end{tabular}

\section{High nitrogen prices}

Similar to the responses about drought, farmers' most common reaction to high nitrogen prices was to reduce fertilizer applications. In contrast to drought, most farmers had more recent memories of dealing with high nitrogen prices, which in 2008 were the highest experienced since 1975 (Fig. 2). In response to a survey question regarding the frequency with which they experienced high fertilizer prices in recent years, $86 \%$ responded "more frequently."

Many farmers regarded nitrogen fertilizer as the largest variable expense on their farm:

My highest input is fertilizer. I'm doing my own soil determinations [using soil tests to assess fertilizer needs ]; I'm deciding whether it's to my advantage to cut that back. They [grain buyers] haven't been paying for protein premiums lately.

Reducing fertilizer applications was perceived to hold the promise of reducing costs, but with a concomitant penalty in yield and revenue. Depending on the additional price premium given to wheat with a higher protein content (requiring higher nitrogen levels), the reduction in fertilizer could further reduce revenue by incurring a low-protein discount.

The unclear relationship between reduced nitrogen application rates and net revenues (ambiguous because a reduction in rates may decrease costs while simultaneously reducing yields) may have prompted at least one farmer to arrive at contradictory views. He reasoned that the price of fertilizer inputs would have little impact simply because of supply and demand:

Well, it would hit me hard, but you know I've jokingly said I just love the hell out of high fertilizer prices, 'cause in retrospect, going back, every time we've had high fertilizer prices we've had high commodity prices... I firmly believe that ... the chemical or the petroleum businesses - they'll bring their prices down. They want to sell their products.
Another subset of farmers expressed resignation to the price of nitrogen, noting that, “...the input cost isn't such a concern ... it is what it is.......and we don't change our rotation based on inputs too much." Combined with the aforementioned responses, the general consensus was that high fertilizer prices merited reduced fertilizer inputs, but this modal response was by no means uniform.

Regardless of their opinions about the impact of high nitrogen prices, all farmers interviewed mentioned pulse crops as a potential solution for reducing nitrogen inputs. Most $(65 \%)$ acknowledged that the "nitrogen credit" associated with using nitrogen-fixing pulse crops was small but worthwhile. Two farmers even mentioned adaptively using pulse crops in response to higher input prices: "We're going to start rotating alfalfa into our rotation and leaving it for a couple years to put [i.e., increase] nitrogen in the ground and cut down our fertilizer costs." Another farmer commented that during the drought in the early 2000s, "We did plant more peas at that time. We actually did because then we didn't have to use the fertilizer. Didn't have to use as much Roundup on the fallow ... right there helps, just being diversified." Despite these views, only two farmers used pulses in response to high input prices, with others choosing pulses for the generalized "rotational benefits" of pest and weed suppression.

In summary, although farmers perceived themselves to have more options for dealing with high fertilizer prices than with drought, the options were still limited and consisted of short-term fertilizer reductions, doing nothing, or, in a few cases, adopting leguminous rotation crops. Every farmer perceived wheat's nitrogen requirements to be fairly static, yet none of the interviewees mentioned the low global average nitrogen use efficiency of less than $50 \%$ (Cassman et al. 2002), which casts doubt on the efficacy of fertilizer, or the prospects of increasing frequency of leguminous rotations as a means to reduce nitrogen applications.

\section{Pathways of adaptation and mitigation}

The previous sections describe that the sequence of reactions to drought or adverse economic conditions result in compounding uncertainty. At the first level of the sequence, fluctuating precipitation and variable prices impact farms in a spatially and temporally heterogeneous manner. At the second level, the variable initial conditions are further scattered by nonuniform responses of crop yield and subsequent revenues. Finally, farmers respond to all of these factors by perceiving and reacting in unique ways to each of the possible scenarios depending on their experiences and personalities. Given the immense array of possible final outcomes, it is worth considering whether there are any consistencies in farmers' adaptation strategies.

Our data suggest that there are some common adaptation patterns in response to novel conditions resulting from climate change or economic stress. Generally, the patterns of choosing agronomic options were consistent with the broader sociological literature on adoption (Rogers and Beal 1958, Mason 1964, Ruttan 1996, Marra et al. 2003), which characterizes the process using the general stages of Awareness, Interest, Evaluation, Trial, and Adoption. Although minor variations on these stages were noted, we outlined farmers' behaviors of gathering information and the adaptation processes to two major stressors. 


\section{Awareness/interest}

Prior to experiencing any form of stress, the interviewed farmers were exposed to a large number of information sources. From these sources, the farmers tended to rely most heavily on personal experience (rated 8.6/10 on a Likert scale), but information from neighbors was also highly valued for learning new agronomic practices (7.5/10). In addition to these primary information sources, most farmers acknowledged their tendency to consult a variety of information sources. One farmer noted, "That's just the way it is now ... you have to collect information from different people and from different information tracks." The farmer further explained, 'Well, when I was growing up ... the county agent was the knower of all things ... I think that that model is maybe not a good model right now, because there's just so much more to know, and you can't be an expert in all things."

\section{Evaluation of information}

Farmers generally perceived a decline in the quality of information provided by some of the previously comprehensive technical sources, which may help explain why the majority of them largely rely on personal experience for day-to-day decisions. The survey data supported this observation, with farmers citing a diversity of sources including internet forums, extension publications, university personnel, chemical dealers, and personal experience for their sources of agronomic information.

The diversity of information available to farmers was further modulated by the personal background and history of each farmer. Many farmers highly valued information learned from their family mentors, "I've been pretty fortunate that they've given me lots of rope. ...We planted seven different crops and we implemented no-till farming ... that's a testimony to the older generation because they've given me the opportunity to do it and by doing it I've kind of proven to them that it works and it's sustainable and it's better for the bottom line." Other farmers placed more importance on the ideas learned from contemporary peers.

\section{Trial}

The diversity of available information exposed farmers to a variety of new practices from different sources, e.g., chemical/seed dealers proposing a new herbicide or farm magazines promoting a new crop. During times of low stress, farmers would selectively experiment with new technology such as precision GPS guidance, no-till seeding, or drought-intolerant crops. However, when farmers were stressed, they unanimously cut back on trials of new practices (excluding use of specific rotations with which they already felt comfortable), operating reactively instead of proactively.

The resulting reflex was to reduce costs and choose conservative options. As one farmer stated, "I think we get more conservative. We have to." In response to the extended period of drought during the 1980s, another farmer said, "We didn't spend anything - you held everything you could, you fixed stuff [equipment] rather than bought new stuff.... You sat tight because you didn't have any money to change anything up." During these periods, adaptation and adoption of new practices was severely limited. The process of information acquisition, interest, and evaluation no longer functioned as normal, and any adaptations that required even a modest level of risk were ruled out.

\section{Adoption}

Farmers' core instinct for economic preservation overrode the desire to adopt new, potentially risky practices, even if these practices could potentially relieve stress. Outside of those periods of stress, the patterns of adaptation were dictated by a consistent set of evaluation criteria expressed by the farmers. The most important criterion was a new practice's economic viability, which meant that it either lowered costs for the farmer, enhanced yields, or tapped into a lucrative market (for a new crop).

Rotation was the second prominent consideration for farmers. Every interviewed farmer emphasized a belief in the value of rotating crops, both for reducing weed and pest issues, for reducing nitrogen costs, and for increasing the intensity of cropping (rather than having years of fallow). One farmer explained, "You're always trying to find better ways to be stewards of the land by trying these rotations so maybe you won't have to use as much fertilizer - using peas or lentils for fixing nitrogen in the ground."

Logistics and the time required to implement new practice was the third most frequently cited constraint for adoption by the interviewees. Most NGP farmers work long hours during the growing season by themselves or with a limited number of other family members or employees, thus the difficulty of troubleshooting new equipment, covering more ground with the herbicide sprayer, or expending other precious time was a significant consideration.

During periods of low stress and when the economic, rotational, and logistical requirements for a new practice were met, farmers would then proceed through the next stages of the adoption process. However, at all points during the process they were highly sensitive to observations or comments by their peers validating or rejecting the proposed practice. These social pressures sometimes irreversibly convinced farmers to abandon their exploration. Social observations (farmers watching neighbor farmers), in particular, were very strong motivators or deterrents and held substantial weight, "I think we just try to see what each other is doing and share those results. A windshield tour will give you an idea of what's going on." As another farmer mentioned, "If it [an idea] doesn't work for them, I don't mess with it." In contrast, if superior results were observed, then the interest of the observing farmers would be elevated.

Finally, during periods of low stress when the previous requirements were met, farmers would stage a trial of the new practice. Without exception, every surveyed farmer mentioned that during periods without stress, they would frequently test new practices. These trials were made on an average of 200 acres. Their motivations for trying new crops or techniques were often driven by a perception of farmer-to-farmer competition:

The thing that's big is just the competitiveness of it all. It's just like anything else, I mean, when you're selfemployed and if your neighbors are getting big deals and big crops, your goal is to get a bigger crop than any of them, but it's from a friendly, competitive standpoint. A lot of stuff is learned from your neighbors or your friends.

The pressure to excel and stand out among peers, and to be viewed as "progressive" drove them toward experimenting more aggressively, "... if you sit around and wait for your neighbors to do it then you're kind of behind. The first one around, I guess, to try new farming practices - that's what I mean by progressive." 


\section{DISCUSSION}

\section{Total stress}

Since 1965, farmers experienced three distinct periods of uncertainty, which were largely driven by the most limiting production factor in the NGP, drought. However, fluctuations in prices amplified total variability in the 1970s and extended the period of uncertainty in the 2000s. As farmers used higher quantities of fertilizer throughout this time period, the effects of fluctuations in the price of nitrogen fertilizer may have been perceived to be even larger, despite associated increases in yields. Farmer adaptation to both prices and drought parallels their temporal predictability, which, as discussed below, suggests specific approaches for increasing adaptability.

\section{Drought adaptations}

Given the paucity of crops and management practices cited by farmers for managing drought, farmers could face serious consequences if a severe drought were to develop in the NGP. Such droughts are not uncommon, with the most severe of the 20 th century occurring during the 1930s and the mid to late 1980s. During such conditions, most farmers stated that they would choose to exclusively plant wheat and fallow their fields more frequently, which they perceived to be economically rational decisions over short time periods. This contrasts the general trend of reduced acres under summer-fallow in the U.S. and in adjacent areas of Canada, even during years of drought (Tanaka et al. 2010). Unfortunately, choosing to fallow may not be rational over longer time scales, because cutting back on rotational crops ultimately reduces long-term resilience to drought by reducing the formation of soil organic matter (West and Post 2002), which is important for retention of soil moisture (Hudson 1994). This is consistent with the observation that adverse events, e.g., extreme drought, that are low-probability, high-consequence, and primarily observable through statistics, e.g., probability of an extreme drought event over a long time period, are less likely to elicit evasive actions than those that have immediate, visible effects (Weber 2006).

\section{Nitrogen price adaptations}

Although rotations were mostly viewed as benefiting weed and pest suppression than mitigating the effects of high nitrogen prices, their status as the second-most cited mitigation technique (behind reducing application rates) points to their future potential. Simply reducing the amount of nitrogen application has the advantage of a quick cost reduction, but it may deplete the pool of soil N and result in lower yields. Leguminous rotations, however, are able to supply a significant quantity of $\mathrm{N}$ to the cash crop, albeit only after use in rotation for six years (Miller et al. 2015, O'Dea et al. 2015). Whether by emphasizing the reduced costs of pest control or by promotion as a way to reduce nitrogen costs, pulse crops are a particularly viable method for increasing resilience to high and uncertain nitrogen prices. Both justifications fit with farmers' primary focus on economic viability.

\section{Adaptability and interacting stressors}

Fluctuations in the climatic and economic stressors occur at different rates and frequencies, yet all are not fully predictable. Prices appear to vary less than the Palmer drought index, giving farmers a better possibility of adapting through the gradual incorporation of pulse crops or other methods of increasing nitrogen use efficiency in times of lower prices. However, the high unpredictability of drought makes adaptation far more difficult and excludes mitigation strategies or experimentation at the time when they are most needed. Implementation of strategies that could increase resilience through crop rotation appear to be slowly increasing, with 51,000 acres devoted to pulse crops in 1998 and greater than 700,000 ( $12.4 \%$ of NGP cropland in Montana) acres in 2013 (USDA-NASS Quickstats 2015). However, adoption is interrupted during periods of drought and it remains unknown whether pulse use will continue to expand.

Periods of intense stress - high price variability and limited soil moisture-are thus unlikely to be advantageous times for increasing farmer adaptability. Farmers' economic flexibility to experimentation is also more limited during these periods because of lower net revenues, and their tendency to return to wheat-fallow will likely trump any beliefs of rotational value. Some economists argue that farmers are correct in hesitating to use rotations because experimentation costs outweigh the value of information gained by waiting for a clearer understanding of future conditions (Lombardi 2009). Yet although this "option value" would be rational for stressors that have somewhat predictable signals and no temporal or spatial variability, it would only be partially true for prices and would not hold true for climatic stressors that are highly variable and uncertain for specific locations.

Thus there exists a conflict between short and long-term economic and agronomic rationality that ultimately serves to decrease the resilience to these stressors during times of drought. Drought mitigation through the improvement of soil organic matter requires 20-60 years (West and Post 2002), and increasing the nitrogen supplying power of soil requires at the very least two to three cropping cycles (O'Dea et al. 2015). Hence, economic incentives may be required to maintain rotations in the presence of drought to increase resilience. These incentives could be made through government policies and aligned with efforts to increase carbon sequestration, as increased levels of organic matter equate to higher levels of carbon stored in the soil. Increasing rotational complexity could therefore simultaneously increase noninput

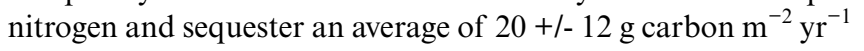
(West and Post 2002). However, without incentives, even producers with stronger long-term motivations to increase organic matter and who are aware of the benefits in doing so (such as organic farmers) are subject to the short-term need to maximize profits (Knutson et al. 2011). Therefore, market development for drought-tolerant crops or policy incentives to increase long-term drought resilience may be required to shift farmer behavior.

\section{CONCLUSION}

Dryland agricultural systems in the NGP are constrained by fluctuating nitrogen and wheat prices and by sporadic, intense drought. The options for mitigating the effects of these stressors are limited and may be inaccessible when conditions are unfavorable and highly unpredictable. However, during periods when drought is not amplifying the effects of price pressures, several trends, if nurtured and properly incentivized, may facilitate more resilient agricultural systems.

First, farmers' belief in the value of rotations may be harnessed to achieve the simultaneous goals of reducing reliance on fertilizer inputs and increasing soil moisture retention, which could be achieved, for example, through legume-based rotations that 
increase soil fertility and soil water retention. Second, if farmers have incentives to experiment even in periods of duress, there can be greater potential for finding agronomic management that is optimal under stressful conditions. Furthermore, if failure of small agronomic trials is less stigmatized, it will reinforce the culture of constant small-scale on-farm experimentation, in turn unearthing long-run successful drought-tolerant practices on each field.

Without an acceleration of rotation use or other mitigation strategies, it is unclear whether periods of intense, unpredictable stress would have increasingly catastrophic impacts. In NGP's marginal agricultural climatic region, many farmers have been forced to exit during high stress conditions. This study suggests that similar outcomes are still possible. If the climatic and economic thresholds that govern crop production in these marginal agricultural systems become more unpredictable, then an even greater number of North American farming systems could be vulnerable to bankruptcy. Thus, effective strategies to increase the resilience of dryland agricultural systems, particularly those that use crop rotations to increase soil organic matter and nitrogen, may provide increased resilience to NGP agriculture.

Responses to this article can be read online at: http://www.ecologyandsociety.org/issues/responses. $\mathrm{php} / 9983$

\section{Acknowledgments:}

This work was supported by a Western Sustainable Agriculture Research and Education Program grant and material based on work supported by the Montana Institute on Ecosystems' award from the National Science Foundation EPSCoR Track-1 program, Grant \# EPS-1101342. Dr. Jill Belsky provided substantial assistance with the conceptualization and initiation of the sociological work. Lisa J. Rew was supported by the United States Department of Agriculture, National Institute of Food and Agriculture, Hatch project MONB00363.

\section{LITERATURE CITED}

Antle, J. M., S. Capalbo, E. T. Elliott, and K. H. Paustian. 2004. Adaptation, spatial heterogeneity, and the vulnerability of agricultural systems to climate change and $\mathrm{CO}_{2}$ fertilization: an integrated assessment approach. Climatic Change 64:289-315. http://dx.doi.org/10.1023/B:CLIM.0000025748.49738.93

Berkes, F., D. Armitage, and N. Doubleday. 2007. Synthesis: adapting, innovating, evolving. Pages 308-327 in D. Armitage, F. Berkes, N. Doubleday, editors. Adaptive co-management: collaboration, learning and multi-level governance. University of British Columbia Press, Vancouver, British Columbia, Canada.

Bradshaw, B., H. Dolan, and B. Smit. 2004. Farm-level adaptation to climatic variability and change: crop diversification in the Canadian prairies. Climatic Change 67:119-141. http://dx.doi. org/10.1007/s10584-004-0710-Z
Bureau of Labor Statistics. 2015. Consumer price index - all urban consumers. Bureau of Labor Statistics, Washington, D.C., USA. [online] URL: http://download.bls.gov/pub/time.series/cu/cu. data.1.Allitems

Cassman, K. G., A. Dobermann, and D. T. Walters. 2002. Agroecosystems, nitrogen-use efficiency, and nitrogen management. Ambio 31:132-140. http://dx.doi.org/10.1579/0044-7447-31.2.132

Cutter, S. L. 1996. Vulnerability to environmental hazards. Progress in Human Geography 20:529-539. http://dx.doi. org/10.1177/030913259602000407

Delgado, J. A., S. Secchi, P. Groffman, M. A. Nearing, T. Goddard, D. Reicocky, R. Lal, P. Salon, N. R. Kitchen, C. Rice, and D. Towery. 2011. Conservation practices to mitigate and adapt to the effects of climate change. Journal of Soil and Water Conservation Society 66(a):118A-129A.

Dillman, D. A. 2000. Mail and internet surveys: the tailored design method. Second Edition. John Wiley, New York, New York, USA.

Hatfield, J. L., K. J. Boote, B. A. Kimball, L. H. Ziska, R. C. Izaurralde, D. Ort, A. M. Thomson, and D. Wolfe. 2011. Climate impacts on agriculture: implications for crop production. Agronomy Journal 103:351-370. http://dx.doi.org/10.2134/ agronj2010.0303

Howden, S. M., J.-F. Soussana, F. N. Tubiello, N. Chhetri, M. Dunlop, and H. Meinke. 2007. Adapting agriculture to climate change. Proceedings of the National Academy of Sciences 104:19691-19696. http://dx.doi.org/10.1073/pnas.0701890104

Hudson, B. D. 1994. Soil organic matter and available water capacity. Journal of Soil and Water Conservation 49:189-194.

Knutson, C. L., T. Haigh, M. J. Hayes, M. Widhalm, J. Nothwehr, M. Kleinschmidt, and L. Graf. 2011. Farmer perceptions of sustainable agriculture practices and drought risk reduction in Nebraska, USA. Renewable Agriculture and Food Systems 26:255-266. http://dx.doi.org/10.1017/S174217051100010X

Lobell, D. B., M. B. Burke, C. Tebaldi, M. D. Mastrandrea, W. P. Falcon, and R. L. Naylor. 2008. Prioritizing climate change adaptation needs for food security in 2030. Science 319:607-610. http://dx.doi.org/10.1126/science.1152339

Lofland, J., D. Snow, L. Anderson, and L. H. Lofland. 2006. Analyzing social settings: a guide to qualitative observation and analysis. Thomson \& Wadsworth, Belmont, California, USA.

Lombardi, D. 2009. Business investment under uncertainty and irreversibility. Oxonomics 4:25-31. http://dx.doi.org/10.1111/ j.1752-5209.2009.00029.x

Marra, M., D. J. Pannell, and A. A. Ghadim. 2003. The economics of risk, uncertainty and learning in the adoption of new agricultural technologies: where are we on the learning curve? Agricultural Systems 75:215-234. http://dx.doi.org/10.1016/ $\underline{\mathrm{S} 0308-521 \mathrm{X}(02) 00066-5}$

Mason, R. G. 1964. The use of information sources in the process of adoption. Rural Sociology 29:40-52.

Maxwell, J. A. 2013. Qualitative research design: an interactive approach. Third edition. Sage, Thousand Oaks, California, USA. http://dx.doi.org/10.1093/obo/9780199756810-0126 
McLeman, R., D. Mayo, E. Strebeck, and B. Smit. 2008. Drought adaptation in rural eastern Oklahoma in the 1930s: lessons for climate change adaptation research. Mitigation and Adaptation Strategies for Global Change 13:379-400. http://dx.doi. org/10.1007/s11027-007-9118-1

Miles, M. B., and M. A. Huberman. 1994. Qualitative data analysis: an expanded sourcebook. Sage, Thousand Oaks, California, USA.

Miller, P. R., A. Bekkerman, C. A. Jones, M. H. Burgess, J. A. Holmes, and R. E. Engel. 2015. Pea in rotation with wheat reduced uncertainty of economic returns in southwest Montana. Agronomy Journal 107:541-550. http://dx.doi.org/10.2134/ agronj14.0185

Mishra, A. K., and H. S. El-Osta. 2002. Managing risk in agriculture through hedging and crop insurance: what does a national survey reveal? Agricultural Finance Review 62:135-148. http://dx.doi.org/10.1108/00214930280001134

National Climatic Data Center. 2015. Historical Palmer z-index data. "climdiv-zndxdv" product. National Climatic Data Center, Asheville, North Carolina, USA. [online] URL: ftp://ftp.ncdc. noaa.gov/pub/data/cirs/climdiv/

Nielsen, D. C., P. W. Unger, and P. R. Miller. 2005. Efficient water use in dryland cropping systems in the Great Plains. Agronomy Journal 97:364-372. http://dx.doi.org/10.2134/agronj2005.0364

O’Dea, J. K., C. A. Jones, C. A. Zabinski, P. R. Miller, and I. N. Keren. 2015. Legume, cropping intensity, and N-fertilization effects on soil attributes and processes from an eight-year-old semiarid wheat system. Nutrient Cycling in Agroecosystems 102:179-194. http://dx.doi.org/10.1007/s10705-015-9687-4

Piringer, G., and L. J. Steinberg. 2006. Reevaluation of energy use in wheat production in the United States. Journal of Industrial Ecology 10:149-167. http://dx.doi.org/10.1162/108819806775545420

Pittman, J., V. Wittrock, S. Kulshreshtha, and E. Wheaton. 2011. Vulnerability to climate change in rural Saskatchewan: case study of the Rural Municipality of Rudy No. 284. Journal of Rural Studies 27:83-94. http://dx.doi.org/10.1016/j.jrurstud.2010.07.004

Quiring, S. M., and T. N. Papakryiakou. 2003. An evaluation of agricultural drought indices for the Canadian Prairies. Agricultural and Forest Meteorology 118:49-62. http://dx.doi. org/10.1016/S0168-1923(03)00072-8

Rogers, E. M., and G. M. Beal. 1958. The importance of personal influence in the adoption of technological changes. Social Forces 36:329-335. http://dx.doi.org/10.2307/2573971

Roling, N. G., and J. Jiggins. 1998. The ecological knowledge system. Pages 304-306 in N. G. Röling and M. A. E. Wagemakers, editors. Facilitating sustainable agriculture: participatory learning and adaptive management in times of environmental uncertainty. Cambridge University Press, Cambridge, UK.

Ruttan, V. W. 1996. What happened to technology adoptiondiffusion research? Sociologia Ruralis 36:51-73. http://dx.doi. org/10.1111/j.1467-9523.1996.tb00004.x

Saltiel, J., J. W. Bauder, and S. Palakovich, 1994. Adoption of sustainable agricultural practices: diffusion, farm structure, and profitability. Rural Sociology 59:333-349. http://dx.doi. org/10.1111/j.1549-0831.1994.tb00536.x

Strauss, A., and J. Corbin. 1998. Basics of qualitative research techniques. Sage, Thousand Oaks, California, USA.

Sunding, D., and D. Zilberman. 2000. The agricultural innovation process: research and technology adoption in a changing agricultural industry. Pages 207-261 in B. Gardner and G. C. Rausser, editors. Handbook of agricultural and resource economics. Elsevier, Amsterdam, The Netherlands.

Tanaka, D. L., D. J. Lyon, P. M. Miller, S. D. Merrill, and B. G. McConkey. 2010. Soil and water conservation advances in the semiarid northern Great Plains. Soil and Water Conservation Advances in the United States 60:81-102.

Tarleton, M., and D. Ramsey. 2008. Farm-level adaptation to multiple risks: climate change and other concerns. Journal of Rural and Community Development 3:47-63.

Tarnoczi, T. 2011. Transformative learning and adaptation to climate change in the Canadian Prairie agro-ecosystem. Mitigation and Adaptation Strategies for Global Change 16:387-406. http://dx.doi.org/10.1007/s11027-010-9265-7

USDA Economic Research Service (USDA ERS). 2002. Farmer bankruptcies and farm exits in the United States, 1899-2002. Washington, D.C., USA. [online] URL: https://www.ers.usda. gov/webdocs/publications/42532/17750 aib788 1 .pdf?v=41233

USDA National Agricultural Statistics Service (USDA-NASS). 2015a. Wheat and flour price relationships, Kansas City (dollars per $(w t$ ). USDA-NASS, Washington, D.C., USA. [online] URL: https://www.ers.usda.gov/webdocs/DataFiles/54282/Wheat\%20DataAll $\% 20$ Years.xls? $v=43140$

USDA National Agricultural Statistics Service (USDA-NASS). 2015b. Fertilizer use and price. USDA-NASS, Washington, D.C., USA. [online] URL: http://www.ers.usda.gov/data-products/ fertilizer-use-and-price.aspx

USDA National Agricultural Statistics Service Quick Stats Database (USDA-NASS Quickstats). 2015. Surveyed historical spring, winter, and durum wheat acreage. USDA-NASS, Washington, D.C., USA. [online] URL: http://www.quickstats. nass.usda.gov

USDA National Agricultural Statistics Service Montana Office (USDA-NASS MT). 2011. State-wide fertilizer Usage. USDANASS Montana Office, Helena, Montana, USA.

Velandia, M., R. M. Rejesus, T. O. Knight, and B. J. Sherrick. 2009. Factors affecting farmers' utilization of agricultural risk management tools: the case of crop insurance, forward contracting, and spreading sales. Journal of Agricultural and Applied Economics 41:107-123. http://dx.doi.org/10.1017/ $\underline{\mathrm{S} 1074070800002583}$

Weber, E. U. 2006. Experience-based and description-based perceptions of long-term risk: why global warming does not scare us (yet). Climatic Change 77:103-120. http://dx.doi.org/10.1007/ $\underline{\text { s10584-006-9060-3 }}$

West, T. O., and W. M. Post. 2002. Soil organic carbon sequestration rates by tillage and crop rotation. Soil Science 
Society of America Journal 66:1930-1946. http://dx.doi. org/10.2136/sssaj2002.1930

Whitlock, C., W. Cross, B. Maxwell, N. Silverman, A. A. Wade. 2017. 2017 Montana climate assessment. Montana Institute on Ecosystems, Montana State University, and University of Montana, Bozeman and Missoula, Montana, USA. 
Appendix 1. Survey questions administered to Montana Grain Growers Association members.

\begin{tabular}{|c|c|c|c|}
\hline No & Question & Response Type & Options \\
\hline 1 & What is your primary occupation? & Text & \\
\hline 2 & What percentage of your farm is irrigated? & $\begin{array}{l}\text { Numeric } \\
\text { Response }\end{array}$ & \\
\hline 3 & What is your age? & $\begin{array}{l}\text { Numeric } \\
\text { Response }\end{array}$ & \\
\hline 4 & $\begin{array}{l}\text { What percentage (if any) of your farm is } \\
\text { certified organic? }\end{array}$ & $\begin{array}{l}\text { Numeric } \\
\text { Response }\end{array}$ & \\
\hline 5 & $\begin{array}{l}\text { What is the average number of acres youg } \\
\text { row crops on each year? }\end{array}$ & Multi-choice & $1-500,501-1500,1501-3000$ \\
\hline 6 & $\begin{array}{l}\text { If in the future precipitation were to decrease } \\
\text { significantly for } 10 \text { years, how many new } \\
\text { crops would you sow on your farm to adapt } \\
\text { to the drought? }\end{array}$ & Multi-choice & $1-6$ \\
\hline 7 & What crops would you choose & open-ended & \\
\hline 8 & $\begin{array}{l}\text { In the above scenario, what other } \\
\text { management practices would you change on } \\
\text { your farm to adapt? }\end{array}$ & open-ended & \\
\hline 9 & $\begin{array}{l}\text { What type and sources (people or otherwise) } \\
\text { would you turn to for guidance on farming } \\
\text { matters if you weren't sure how to deal with } \\
\text { decreased precipitaton Rate the following } \\
\text { sources (by ticking a box) where } 1 \text { indicates } \\
\text { you wouldn't use the source at all and } 10 \\
\text { indicates you would definitely consult the } \\
\text { source }\end{array}$ & Likert & $\begin{array}{l}\text { Internet forums, farm magazines, extension } \\
\text { agents, university/extension personnel (not } \\
\text { agents)/websites, crop advisers, chemical/crop } \\
\text { dealers/associated websites, other } \\
\text { farmers/neighbors, family members, personal } \\
\text { experience, other (please list) }\end{array}$ \\
\hline 10 & $\begin{array}{l}\text { Of the following extreme events that may } \\
\text { have impacted your production, have you } \\
\text { experienced them more frequently, less } \\
\text { frequently, or no change? }\end{array}$ & Multi-choice & $\begin{array}{l}\text { hail, prolonged drought, flooding, unexpected } \\
\text { freezes, low crop prices, high input prices, pest } \\
\text { outbreaks, severe weed competition }\end{array}$ \\
\hline 11 & $\begin{array}{l}\text { If the extreme events listed above became } \\
\text { more frequent in the future, how would you } \\
\text { respond (e.g. plant new crops, longer fallow } \\
\text { periods, expanded acreage)? }\end{array}$ & open-ended & \\
\hline 12 & $\begin{array}{l}\text { What additional resources would you require } \\
\text { to make the change (e.g. more info on } \\
\text { drought tolerant crops, additional gov't } \\
\text { support)? }\end{array}$ & open-ended & \\
\hline 13 & $\begin{array}{l}\text { How have you specifically altered your } \\
\text { farming practices since you started farming } \\
\text { (e.g. switching to no-till, using guidance, } \\
\text { increased number of crops in rotation, hiring } \\
\text { farm workers)? What motivated you to } \\
\text { perform the change? }\end{array}$ & $\begin{array}{l}\text { Yes/No and } \\
\text { open-ended }\end{array}$ & $\begin{array}{l}\text { more crops in rotation, pulses/legumes in } \\
\text { rotation, stopped/reduced summer fallow, no- } \\
\text { tillage, minimum tillage, precision guidance, } \\
\text { variable fertilizer application, variable } \\
\text { herbicide/fungicide application, } \\
\text { increase/variable seeding rates, yield mapping, } \\
\text { protein mapping, soil mapping, hiring more } \\
\text { farm workers, hiring less farm help, } \\
\text { outsourcing help (e.g. contract harvesting), } \\
\text { organic from conventional, other }\end{array}$ \\
\hline 14 & $\begin{array}{l}\text { When you made those decisions, did you get } \\
\text { your information from the same places listed } \\
\text { in question } 8 \text { ? If not, who or what did you } \\
\text { use? }\end{array}$ & open-ended & \\
\hline
\end{tabular}

